\title{
Mendefinisikan Ulang Pluralisme Agama sebagai Sebuah Tantangan Global
}

\author{
Gunawan Adnan
}

UIN Ar-Raniri Nangroe Aceh Darussalam

enjoyful2002@yahoo.de

Abstract: This paper will try to answer some questions about religious pluralism. Does religious pluralism mean to receive the truth of all religions, as expressed by their founders, although of some religious doctrines are contradictory to each other? What kind of the religious pluralism concept that will be able to resolve the problems of conflict based on religion? Are there other options that can be applied in resolving these problems?

Keywords: Religion, conflict, pluralism.

Abstrak: Tulisan ini akan berusaha menjawab beberapa pertanyaan seputar pluralisme agama. Apakah pluralisme agama berarti mengakui kebenaran semua agama, sebagaimana yang diekspresikan oleh para pendirinya, meskipun beberapa doktrin keagamaan bertentangan satu sama lain? Konsep pluralisme agama seperti apa yang mampu menjadi jalan keluar dari konflik-konflik berdasarkan agama? Apakah ada solusi lain yang dapat ditawarkan sebagai jalan keluar atas problem-problem itu?

Kata Kunci: agama, konflik, pluralisme. 


\section{Pendahuluan}

Indonesia adalah sebuah negara yang sangat plural. Pluralitas Negara Kesatuan Republik Indonesia (NKRI) bisa dilihat dari keanekaragaman ras, suku, bahasa (daerah), adat istiadat dan agama. Bisa jadi keberagaman ini menjadi sebuah kekayaan dan potensi yang dapat dijadikan sebagai modal pembangunan bangsa, di samping kekayaan-kekayaan lainnya. Namun kekayaan ini jika tidak dikelola dengan baik dapat menjadi ancaman yang berakibat fatal. Berbagai keberagaman yang ada di NKRI pun dapat menjadi ancaman bagi keutuhan dan kelangsungan NKRI, karena kelangsungan dan keutuhan suatu negara bergantung pada stabilitas negara yang bersangkutan. Keberagaman dapat dijadikan amunisi untuk memecah persatuan yang bisa berakhir pada hancurnya stabilitas negara. Munculnya usaha untuk disintegrasi di berbagai wilayah RI menjadi bukti konkrit dari potensi konflik atau permasalahan ini.

Beberapa tahun lalu bahkan sampai saat ini, di Indonesia banyak kejadian yang salah satu pemicunya disebabkan kasus SARA. Peristiwa Ambon, Poso, Sampit, Aceh sampai kasus dukun santet di Jawa Timur, semua diisukan bersumber dari SARA, lebih khusus masalah agama. Agama adalah objek yang paling gampang untuk dijadikan kambing hitam. Bentrok antar pendukung partai berbasis agama yang pernah terjadi di beberapa daerah menjadikan agama pun dianggap sebagai biang keroknya. Perkara kriminalitas dengan jelas disebabkan murni politik, namun agama dijadikan sasaran pengambinghitaman

Indonesia bukan negara agama atau madzhab, namun Indonesia adalah negara agamis. Dalam arti, tatanan kenegaraan NKRI tidak didasari oleh ideologi agama atau madzhab tertentu, namun negara dan bangsa Indonesia sangat menjunjung tinggi norma-norma keagamaan. Sehingga, segala pemikiran dan usaha untuk menggeser norma-norma agama akan tersingkir dari lubuk bangsa. Disisi lain, bangsa Indonesia memiliki corak dan watak masyarakat Timur yang kental dengan toleransi, teposeliro (tenggang rasa) dan gotong-royong antar sesama. Oleh karenanya, segala bentuk tindak kriminal, kekerasan dan arogansi baik dengan kemasan premanisme, intelektualisme, maupun spiritualisme agama sekalipun akan mendapat reaksi keras dari berbagai lapisan masyarakat. Dapat kita saksikan, betapa keras 
reaksi masyarakat Indonesia terhadap munculnya berbagai aliran pemikiran liberal berkedok agama yang dalam banyak hal tiada lagi mengindahkan batas-batas norma dan sakralitas keagamaan. Sebagaimana dapat disaksikan reaksi keras masyarakat atas tindak kekerasan dan prilaku arogansi atas kasus-kasus tertentu, khususnya dengan mengatasnamakan agama.

Di sisi lain, usaha pihak-pihak tertentu dalam memunculkan bentrok antar masyarakat dengan isu SARA sering dijumpai dalam banyak kasus di Tanah Air, baik dari luar, maupun dari dalam negeri yang mendapat dukungan luar. Mereka berusaha untuk memecahbelah persatuan dan kesatuan RI dengan menggoyah stabilitas nasional, dengan alasan apapun. Gerakan reformasi pun dijadikan alasan dan sarana untuk itu. Perbedaan agama adalah objek menarik buat kalangan itu untuk membikin keonaran di Nusantara.

Melihat fenomena-fenomena di atas tadi, banyak para pakar menawarkan wacana pluralisme agama dan madzhab sebagai alternatif dan solusi untuk mengatasi probem di atas. Namun bukan berarti permasalahan bisa selesai, namun wacana ini masih menyisakan banyak pertanyaan, seperti apa yang dimaksud dengan pluralisme agama? Adakah pluralisme agama berarti pengakuan akan kebenaran semua agama sebagaimana yang diungkapkan oleh pendirinya, meskipun doktrin beberapa agama saling kontradiktif? Apakah hanya berbekal pluralisme agama akan dapat menyelesaikan permasalahan? Adakah solusi lain yang dapat diterapkan dalam menyelesaikan problem tersebut? Makalah ini paling tidak akan mencoba menjawab pertanyaan-pertanyaan di atas.

\section{Sejarah Lahirnya Pluralisme Agama}

Plural secara etimologis berarti majemuk atau beragam. Istilah ini-sebagaimana banyak istilah lain dalam ranah sosial, politik, falsafat dan teologi-diproduksi Barat. Melalui proses interaksi antara Barat dengan negara-negara dunia ketiga, pengdopsian pemikiran pun dilakukan oleh pemikir dan intelektual negara-negara dunia ketiga. Menurut istilah falsafat agama, pluralisme sering diartikan sebagai keyakinan akan kebenaran semua agama yang ada. Sebelum muncul konsep pluralisme agama, lebih dahulu berkembang ke permukaan 
berbagai pluralisme lain: pluralisme sosial, pluralisme budaya dan pluralisme etika. Pluralisme sosial yang diartikan sebagai penyesuaian terhadap berbagai pandangan dan keyakinan lain secara normal (tidak keluar dari dua titik ekstrim) dengan mengedepankan jiwa toleransi. Pluralisme etika diartikan sebagai relatifitas norma-norma etika dan penafian atas tolok ukur yang bersifat konstan dalam menentukan norma-norma etika yang ada. Sedang pluralisme budaya berarti pengakuan akan kebenaran semua budaya yang ada dan penafian dominasi budaya tertentu. Meskipun terdapat perbedaan jika ditinjau dari sisi fungsinya, namun terdapat kesamaan antara semua bentuk pluralisme tadi, yaitu keyakinan akan relatifitas epistemologis. Dari sinilah, muncullah konsekuensi bahwa segala bentuk parameter, rujukan dan penafsiran yang tetap dan tunggal dinafikan.

Istilah pluralisme agama pertama kali muncul di dunia Barat pada abad keduabelas, pada masa Yohanes Damasyqī. Akan tetapi pada saat itu, istilah pluralisme ini belum terlalu populer. Hingga pada akhirnya, pada tahun 1854 pusat gereja Katolik mengeluarkan statemen resmi bahwa selain agama Kristen, hanya Islam (agama di luar Kristen) yang tidak meyakini ketuhanan al-Masị dinyatakan memiliki muatan kebenaran. Di tahun yang sama (1854), John Hick mengeluarkan pernyataan dan memrotes keputusan pihak gereja Katolik tersebut dengan menyatakan, "Kenapa hanya satu agama saja? Bukankah agama yang lain pun memiliki hak yang sama? Bukankah setiap pengikut agama jika mengikuti suara tulus hati nurani (fitrah) mereka tidak termasuk kategori pendosa?" John Hick memandang perlu adanya pengakuan gereja atas agama-agama semuanya, tanpa terkecuali. Kritisi John Hick atas pandangan pihak gereja inilah yang sekaligus membidani lahirnya pemikiran baru tentang konsep pluralisme agama yang kemudian dalam istilah teologi dikenal dengan Revolusi Coopernicus. ${ }^{1}$

Menurut bapak pluralisme agama, Jonh Hick, keyakinan keagamaan masyarakat dalam kaitannya dengan hubungan antar pengikut agama (atau madzhab) lain terbagi atas tiga kelompok. Pertama, eksklusivisme, yang meyakini bahwa hanya terdapat satu agama yang memiliki muatan kebenaran. Dengan meyakini agama yang satu tersebutlah manusia akan mendapat kebahagiaan dan 
keselamatan sejati. Karl Barth, Emil Brunner dan Hendrik Kraemer, di antara para teolog Protestan yang mewakili pemikiran ini. Mereka menyatakan hanya pada al-Masīh Tuhan memunyai penjelmaan utuh. Oleh karenanya hanya melalui Kristiani manusia akan mendapat penjelmaan mutlak Tuhan. Kedua, pluralisme. Meskipun pluralisme memiliki berbagai pengertian akibat perluasan makna, namun secara umum mereka mengartikan pluralisme agama sebagai pengakuan kebenaran atas semua agama, di mana setiap agama dapat menghantarkan pengikutnya menuju kepada kebahagiaan dan keselamatan sejati, sebagaimana yang didefinisikan oleh pendirinya. Ketiga, inklusivisme, yang seakan merupakan gabungan antara eksklusivisme dan pluralisme. Mereka meyakini hanya ada satu agama yang memiliki kapasitas kebenaran dan dapat menjamin para pengikutnya untuk mendapatkan kebahagiaan abadi. Dari sisi ini mereka sama seperti kaum eksklusivisme. Namun dari sisi lain mereka juga meyakini bahwa kasih sayang dan pertolongan Tuhan mencakup semua pengikut agama-agama yang ada, meskipun ajaran agama yang benar belum mereka dapatkan, atau bahkan sama sekali belum mereka dengar, sebagaimana yang digagas Karl Rahner (teolog Katolik) tentang teori Anonymous Christians, bagi yang berbuat kebaikan tapi tidak memeluk agama Kristen.

Kendala adanya pemikiran eksklusivisme inilah yang dianggap sebagai penghalang terwujudnya ketentraman dan perdamaian antar umat beragama. Ya, walaupun inklusivisme dalam beberapa hal sama seperti apa yang diyakini eksklusivisme, namun keyakinan akan cakupan kasih sayang Tuhan itulah yang menyebabkan mereka masih dapat hidup tentram dan damai bersama para pengikut ajaran agama/ madzhab lain.

John Hick bukan hanya tidak menerima pemikiran eksklusivisme, namun ia juga dengan tegas menolak inklusivisme. Dia mengatakan, "berpikiran inklusivisme saja tidak cukup, harus ada pengakuan akan kebenaran agama-agama lain". ${ }^{2}$

\section{Pluralisme Agama dan Madzhab}

Jika melihat realita kehidupan masyarakat, keberadaan agama dan madzhab dengan berbagai bentuknya merupakan fenomena yang 
tidak dapat dipungkiri. Berangkat dari sini, para intelektual agama diharuskan memberikan pandangannya atas keberadaan berbagai agama dan madzhab tadi, sehingga jelas reaksi apa yang bakal dilakukan oleh penganut agama yang bersangkutan atas penganut agama lain. Di sisi lain, dapat dilihat bahwa pengetahuan dan pemahaman para intelektual agama (ruhaniawan) dalam memahami konteks agama sangat beragam. Dari sinilah akhirnya muncul berbagai pertanyaan yang berakhir pada keyakinan relatifitas pemahaman yang berakhir pada relatifitas kebenaran. Sesuai dengan apa yang disampaikan oleh pendiri pemikiran pluralisme agama, plualisme agama berarti pengakuan akan kebenaran setiap agama.

Jika dianalisis secara teliti ada dua macam bentuk pluralism: pluralisme eksternal agama dan pluralisme internal agama. Pluralisme eksternal agama adalah keyakinan akan kebenaran semua agama, baik dalam kapasitas yang sama maupun dengan kapasitas kebenaran yang berbeda-beda. Sedangkan pluralisme internal agama adalah keyakinan akan kebenaran semua sekte/madzhab dalam satu agama tertentu, di mana letak perbedaan antar sekte/madzhab adalah disebabkan oleh perbedaan penafsiran (hermeneutika) terhadap konteks agama. Pluralisme internal agama muncul akibat keyakinan akan kebenaran semua bentuk penafsiran, walaupun satu sama lain secara zahir saling bertentangan. Hal itu adalah untuk menghindari terjadinya pertikaian antar pengikut sekte/madzhab dalam kehidupan bermasyarakat.

Kedua bentuk pluralisme di atas (internal dan eksternal agama) memiliki beberapa kemungkinan pengertian yang berbeda. Pertama, pluralisme diartikan sebagai pandangan atas agama/madzhab sebagai satu hakikat namun dengan berbagai rupa dan bentuk. Kedua, pluralisme diartikan sebagai esensi hakikat memiliki berbagai bentuk yang terjelma dalam berbagai agama/madzhab. Ketiga, pluralisme diartikan bahwa hakikat terdiri dari berbagai unsur yang masingmasing dari unsur yang ada tersimpan dalam sebuah agama/madzhab. Dan keempat, pluralisme diartikan sebagai saling menghormati antar pengikut umat beragama/bermadzhab, toleransi sosial antar umat beragama/bermadzhab. ${ }^{3}$

Tentu, antara konsep dan praktik memiliki hubungan yang sangat erat. Masing-masing arti dari empat alternatif pemahaman di 
atas sangat berpengaruh pada sikap pribadi pemilik konsep. Singkat kata, setiap arti apapun yang dipilih pada empat pengertian di atas masing-masing memiliki konsekuensi logis yang berpengaruh pada prilaku empunya. Kesalahan dalam memahami konsep pluralisme agama akan menyebabkan kesalahan dalam bertindak. Jika pluralisme diartikan sebagai pengakuan akan kebenaran setiap agama, atau tercecernya kebenaran ataupun adanya gradasi kebenaran, maka hal itu akan memunculkan berbagai paradoksi dalam logika seseorang. Akal sehat manusia tidak akan bisa menerima bahwa dua hal yang saling paradoks sama-sama memiliki muatan kebenaran. Ketika dijumpai dua ajaran yang saling kontradiktif, mustahil keduanya dihukumi benar. ${ }^{4}$

\section{Problematika Konsep Pluralisme Agama}

Melihat sejarah kemunculan dan fenomena yang terjadi di Barat, konsep pluralisme agama, yang juga menjadi diskursus pemikiran di Indonesia, dihadapkan dengan dua problematika. Pertama, problematika epistemologi. Persoalan ini berkaitan dengan keyakinan akan relatifitas kebenaran, atau keyakinan akan ketidakmampuan dan kelemahan manusia dalam meraih kebenaran sejati. Para pendukung pemikiran ini selalu melihat sesuatu dengan kacamata skeptisisme. Dalam dunia Kristen, para pendukung pemikiran pluralis, mereka bukan hanya meragukan kebenaran agama Kristen, dalam banyak hal mereka ragukan, sampai-sampai keberadaan (dalam sejarah) Nabi ‘Īsā al-Masīh pun mereka ragukan. Sebagaimana mereka juga meragukan kitab suci Injil yang mereka katakan sebagai hasil karya para sahabat dari sahabat al-Masīh, dengan syarat kalaulah al-Masīh pernah ada di dunia.

Kedua, problematika politik dan budaya masyarakat. Walaupun faktor ini bukan faktor dasar terbentuknya pluralisme agama, yang berarti kebenaran semua keyakinan dan agama, namun, sedikit banyak memunyai pengaruh dalam konsep itu. Konsep yang sekularisme banyak dipengaruhi oleh faktor di atas, bukanlah pluralisme agama.

Melihat dari dua problematika di atas, pada dasarnya ada tiga poin yang harus dibahas dalam permasalahan pluralisme agama yang berkaitan dengan problem epistemologis. Pertama, pembahasan 
teoritis. Masalah utama dalam pembahasan ini bersumber dari pertanyaan, adakah satu di antara sekian banyak agama dan sekte yang dapat mewakili kebenaran mutlak, sehingga dapat menjadi parameter benar-salah golongan lain? Ataukah proses menimbang kebenaran dan kesalahan setiap golongan merupakan suatu hal yang relatif, sehingga tidak ada satu agama dan madzhab pun yang dapat mewakili kebenaran secara utuh? Kesimpulan terakhir yang diambil adalah tidak ada satu agama dan madzhab pun yang dapat mewakili kebenaran mutlak. Inilah yang dipakai sebagai dasar para pendukung pluralisme agama dan madzhab.

Kedua, pembahasan keselamatan abadi. Problem utama dalam pembahasan ini bersumber dari pertanyaan; apakah pengikut yang taat dalam setiap agama dan aliran akan mendapat kebahagiaan abadi? Ataukah hanya pengikut yang taat pada agama atau madzhab tertentu yang dapat menikmati kebahagiaan abadi? Tentu, para pendukung pluralisme agama akan menjawab bahwa pelaku ketaatan pada setiap agama akan mendapatkan kebahagiaan dan keselamatan abadi. Hal itu dikarenakan keyakinan akan kebenaran semua agama/madzhab dan tiada satu pun dari agama/madzhab tersebut yang mewakili kebenaran mutlak.

Ketiga, pembahasan praktis (hidup rukun dan damai antar sesama umat beragama). Titik penting pembahasan ini yakni; mungkinkah masyarakat yang berbeda agama dan madzhab akan dapat hidup rukun dan damai saling berdampingan? Ataukah kehidupan rukun dan damai hanya dapat terealisasi jika masyarakat menganut satu agama/madzhab? Para pendukung pluarisme agama-berdasarkan dua pemikiran sebelumnya-akan menjawab positif. Mereka akan mengatakan bahwa dengan bekal pluralisme agama (dengan arti yang disebutkan oleh pendirinya) hidup rukun dan damai antar umat beragama akan dapat terwujud. ${ }^{5}$ Perlu dicatat bahwa bukan hanya para pendukung pluralisme agama saja yang menjawabnya dengan jawaban positif, namun para pengritisi konsep pluralisme agama pun menjawabnya dengan positif.

Para pendukung pluralisme beranggapan bahwa tiga poin di atas saling berkaitan, sehingga dengan menolak salah satunya akan gugur semuanya. Mereka menyatakan, jika seseorang telah meyakini 
pluralisme agama yang berarti pengakuan akan kebenaran semua agama/madzhab (pada poin pertama), maka ia akan meyakini bahwa setiap pemeluk agama/madzhab lain, jika mereka taat atas ajaranajarannya, niscaya bakal mendapat keselamatan dan kebahagiaan abadi (pada poin kedua). Jika keyakinan pada poin kedua tadi sudah melekat pada jiwa seseorang, maka ia akan selalu berjiwa toleran terhadap semua orang yang berlainan agama/madzhab. Padahal tidak ada konsekuensi logis antara ketiga poin di atas tadi. Bisa saja seseorang menolak salah satu dari tiga poin tadi -misalnya menolak sisi teoritis karena ketidak-logisannya- namun ia mengambil poin yang lain, sisi praktisnya, karena lebih dapat diterapkan. ${ }^{6}$ Di sini, tidak ada konsekuensi jika menerima sisi praktis maka secara otomatis pasti menerima sisi teoritisnya. ${ }^{7}$

Sebagaimana yang telah dibahas di atas, faktor epistemologislah yang lebih dominan dalam pelontaran konsep pluralisme agama; bisa dikatakan pluralisme agama adalah kelanjutan dari skeptisisme dan sophisme Yunani klasik dengan sedikit modifikasi, yang meyakini relatifitas kebenaran. Oleh karenanya, pluralisme berkaitan erat dengan konsep-konsep rasional, bukan eksperimental. Konsep-konsep rasional dalam pokok pembahasan agama secara khusus dibahas dalam pembahasan teologi dan falsafat. Yang dimaksud dengan rasio di sini adalah pendeteksi di luar indera, imajinasi (khayalan) dan prasangka, ${ }^{8}$ atau biasa disebut dengan akal demonstratif ('aql burhānī) yang menghasilkan konklusi dari proposisi-proposisi universal, di mana mayor dan minor dalam proses pendeduksiannya dapat dipertanggungjawabkan kebenarannya.

\section{Kritik Konsep Pluralisme}

Ada beberapa hal yang menjadi dasar utama pemikiran pluralisme agama yang harus dicermati secara kritis. Hal ini perlu supaya jika ditemukan banyak kelemahan dalam bangunan argumentasinya maka secara konseptual ide tersebut harus direkonstruksi ulang sehingga akan muncul konsep baru yang lebih komprehensif dan tepat untuk diimplementsikan. Di antara beberapa hal yang harus dicermati adalah sebagai berikut:

Pertama, metode dalam mengenal hakikat agama. Banyak 
ilmuwan dalam meneliti fenomena keagamaan menggunakan metodologi yang sesuai dengan latar belakang pendidikan mereka. Tidak jarang metodologi yang mereka terapkan tidak menjurus kepada hakikat (esensi) agama yang mereka teliti, tetapi hanya tertuju pada fenomena zahir suatu agama.

Ada tiga metode yang sering dipakai oleh para ilmuwan. ${ }^{9}$ Sosiolog berkesimpulan bahwa agama merupakan fenomena sosial yang beragam. Jelas, mengetahui esensi agama dan kaitannya dengan benar-salah suatu ajaran agama tidak dapat dideteksi secara teliti melalui metode sosiologi ini. Begitu juga dengan sebagian psikolog yang beranggapan bahwa agama terwujud dari ciri khas kejiwaan setiap pribadi manusia. Menurutnya, setiap individu memiliki cara dan sarana untuk berhubungan dengan eksistensi jiwanya. Dengan sarana tersebut akhirnya individu tadi menjadi individu agamis. Meskipun metode semacam ini secara mutlak tidak dapat disalahkan karena dapat membantu manusia dalam proses pencarian agama, akan tetapi metode semacam ini tetap tidak dapat mengenal secara detail ciri khas agama yang benar. Lain halnya dengan penelitian sejarah dan geografi yang pada batas-batas tertentu sangat bermanfaat, namun tetap tidak dapat menilai secara objektif kebenaran sebuah ajaran agama/madzhab.

Metode yang tepat dalam mengenal agama dan menentukan kebenaran ajaran suatu agama/madzhab hanya dapat dilakukan melalui metode intelektual. Tentu metode ini tidak bersifat membumi, dalam arti, hanya pribadi-pribadi tertentu saja yang dapat menalar dan memraktikannya. Menganut ajaran agama yang benar adalah ajakan abadi esensi dasar manusia (fitrah) dan akal sehat manusia. Ajakan fitrah dan akal sehat manusia untuk selalu mengikuti agama yang benar dikarenakan hanya agama yang dapat memenuhi segala kebutuhan spiritual manusia. ${ }^{10}$ Adapun hal-hal rasional yang sesuai dengan akal sehat manusia hanya dapat diraih melalui metode yang diajarkan oleh ajaran falsafat dan teologi. Melalui metode falsafat dan teologi seorang pribadi dapat meraih keyakinan sejati yang sesuai dengan realita, bukan keyakinan sosiologis, psikologis atau sejarah. Tidak semua keyakinan bersifat ilmiah yang dapat dipertanggungjawabkan kebenarannya, terkadang keyakinan juga 
bersifat psikologis yang muncul akibat doktrin yang dilakukan secara berulang. ${ }^{11}$

Kedua, relatifitas pemahaman dan kaitannya dengan keragaman. Mereka meyakini bahwa tidak ada satu pun yang ada di alam realita ini yang secara menyeluruh dapat diketahui oleh manusia. Mereka berdalil, semua yang ada di semesta bersifat tidak terbatas (absolut), sedang akal manusia bersifat terbatas. Lantas, bagaimana mungkin yang terbatas akan mengetahui secara detail hal-hal yang tidak terbatas? Oleh karenanya, setiap pemahaman manusia akan sesuatu -yang sesuai dengan kadar masing-masing individu- membawa nilai kebenaran. ${ }^{12}$

Konsep ini harus dipertanyakan terlebih dahulu, manakah realita yang tidak terbatas? Jika yang dimaksud dengan realitas yang tidak terbatas adalah wujud mumkin (possible existence) maka pernyataan ini tidak dapat dibenarkan, mengingat semua kenyataan alam realita bersifat terbatas sebagaimana yang telah ditetapkan dalam falsafat dan teologi. ${ }^{13}$ Jika yang dimaksud dengan tidak terbatas adalah gabungan penciptaan alam semesta secara keseluruhan maka hal ini dapat diterima, namun tidak seorang pun yang mengaku bahwa pemahamannya mencakup semua hakikat baik yang berkaitan dengan zaman dahulu, sekarang dan akan datang. Atau jika yang dimaksud dengan tidak terbatas adalah eksistensi Tuhan, maka jelas tiada seorang pun yang mengaku telah mampu melingkupi-Nya.

Mungkin saja dapat dikatakan bahwa tidak seorang pun dapat meraih hakikat absolut, akan tetapi ungkapan tadi tidak dapat diambil kesimpulan bahwa semua yang dipahami oleh setiap orang atau kelompok adalah memiliki muatan kebenaran. Tentu, akal tidak akan membenarkan ungkapan yang mengatakan, "ungkapan seorang pakar kedokteran tentang masalah penyakit A belum tentu mutlak benar, namun ungkapan si X yang tidak pernah belajar sedikit pun tentang penyakit dan kedokteran, dalam masalah penyakit $\mathrm{A}$, juga memiliki muatan kebenaran". ${ }^{14}$ John Hick, berkaitan dengan hal ini menyandarkan argumentasinya dengan analogi Jalāluddīn Rūmī (Mawlāwī) penginderaan beberapa orang terhadap gajah di dalam ruangan gelap gulita. Padahal Mawlāwī Rūmī tidak mengatakan bahwa semua persepsi manusia tentang gajah di dalam kamar gelap itu 
dinyatakan betul. Namun ia mengatakan bahwa persepsi semua orang tentang gajah adalah salah. Akan tetapi karena mereka pada situasi gelap tanpa ada cahaya penerang sedikit pun, maka kesalahan mereka masih bisa ditolerir. Mereka harus tetap berusaha untuk mencari lampu penerang sehingga dapat mengindera gajah sebagaimana mestinya. Jika ada seseorang, setelah mendapat lampu penerang, dengan sengaja pergi ke dalam kegelapan untuk mengindera gajah, dan jika ia terjerumus ke dalam kesalahan, niscaya kesalahannya tidak lagi dapat ditolerir. Hanya dengan cahaya ma'rifat yang terpancar dari akal demonstratif manusia akan mendapat kebenaran sejati yang bersifat tunggal, tidak berbilang.

Ketiga, reaksi pemahaman manusia terhadap realita. Sebagian beranggapan bahwa perubahan pemahaman manusia sangat dipengaruhi oleh perubahan realitas di luar. Mereka berdalil, kebenaran bukanlah sesuatu yang berada dalam pikiran manusia. Pendeteksian alam realita tergantung kepada sel-sel saraf otak setiap individu yang kemudian diolah menjadi pengetahuan individu tersebut. Oleh karenanya, pengetahuan setiap individu sangat bergantung kepada kemampuan penginderaan sel-sel saraf yang terdapat pada otak masing-masing. Bagi sebagian ilmuwan, pemikiran semacam ini bukan hanya berkaitan dengan alam natural saja, namun juga dapat diterapkan pada pemahaman manusia terhadap agama.

Pemikiran ini tentu tidak dapat diterima, mengingat pengetahuan manusia tidak hanya bergantung kepada sel-sel saraf otak yang bersifat materi. Dalam istilah falsafat, sel-sel saraf otak berkaitan dengan pengetahuan manusia hanya sebagai alat atau sebab pemberi sarana (preparing cause) saja. Pengetahuan manusia bersumber dari kemampuan berfikir dan esensi manusia penghasil keyakinan ilmiah sekaligus semangat pengamalan sebuah konsep. Semua itu bersifat non-materi. Oleh karenanya, boleh jadi otak yang terdapat pada badan materi manusia berposisi pada satu kotak tertentu, namun kemampuan berpikir manusia bisa melalangbuana ke segala penjuru dunia, bahkan alam semesta. Itulah salah satu ciri eksistensi nonmateri, tidak dipengaruhi ruang dan waktu. Meskipun masingmasing individu memiliki ciri khas tersendiri dalam sistem sel saraf otak sebagai sarana penghasil pengetahuan, akan tetapi perbedaan 
fasilitas, sistem dan sarana yang ada bukan berarti juga menyebabkan perbedaan kemampuan berpikir (untuk mencapai pengetahuan). Jika perbedaan sel-sel saraf manusia menjadi dasar utama perbedaan pengetahuan (terkhusus dalam menentukan benar-salah), lantas bagaimana cara seseorang melakukan proses pemindahan pengetahuan melalui kegiatan belajar-mengajar dalam sebuah kelas? Bagaimana seorang guru dapat menyalahkan jawaban seorang murid yang salah dan tidak sesuai dengan apa yang diajarkannya? Maka otak adalah sarana untuk memahami bukan pemahaman itu sendiri.

Semenjak usia kanak-kanak manusia terbiasa dengan penggunaan inderanya. Hal itu akhirnya menyebabkan kecenderungan manusia terhadap pemakaian indera dalam menilai banyak hal semakin bertambah. Eksperimen merupakan bentuk penelitian inderawi. Eksperimen tidak akan pernah berlaku dalam hal-hal yang berkaitan dengan benar-salah sebuah agama/madzhab, karena banyak ajaran agama/madzhab yang tidak dapat dideteksi melalui proses eksperimen karena bersifat supra-natural. Jelas, sesuatu yang tidak dapat dieksperimenkan, maka untuk mengetahui kebenaran dan kesalahannya pun tidak dapat melalui jalur eksperimen. Masalah keyakinan-keyakinan dasar agama seperti ketuhanan, kehidupan setelah mati, surga-neraka dan sebagainya tidak mungkin dieksperimenkan. Kalaupun terdapat permasalahan etika dan hukum-hukum agama yang dapat dieksperimenkan, hal itu hanya berkaitan dengan hal-hal duniawi belaka, efek inderawi. Sedangkan hubungan etika dan hukum tadi dengan kehidupan pasca kematian, sama sekali tidak dapat dieksperimenkan. Oleh karenanya, untuk mengetahui pandangan dunia keagamaan maupun ajaran-ajaran agama hanya dapat dideteksi melalui jalur rasionalitas ajarannya. Kalaupun dikatakan bahwa hanya melalui eksperimen kebenaran ajaran agama/madzhab dapat diketahui kebenarannya, niscaya hal itu akan membutuhkan banyak waktu untuk mengetahuinya, mengingat banyaknya agama dan madzhab dengan berbagai bentuk ajarannya yang satu persatu harus diteliti. ${ }^{15}$

Dalam kaitannya dengan konsep pluralisme agama/madzhab, harus ditekankan bahwa ada hubungan erat antara disiplin ilmu humaniora dengan pengetahuan agama. Mengingat bahwa fungsi 
agama adalah untuk menghantarkan manusia menuju kebahagiaan dan keselamatan abadi. Tanpa mengenal esensi manusia beserta kebutuhan-kebutuhan, serta mengenal sarana rasional yang harus ditempuh dalam memenuhi segala kebutuhan untuk mendapat kebahagiaan sejati dari cara hidup rasional, mustahil suatu ajaran dapat berfungsi sebagaimana mestinya. Jika dalam ilmu humaniora telah ditetapkan bahwa manusia memiliki satu esensi utama yang tidak berubah sepanjang zaman (yang biasa disebut dengan ruh) sedang yang selalu berubah adalah sisi materi diri manusia saja, maka asas-asas agama (ushuluddin) ${ }^{16}$ yang berfungsi memenuhi kebutuhan sesuatu yang tidak berubah juga harus tetap, tidak berubah. Sedang yang berubah adalah yang berkaitan dengan cabang-cabang agama $\left(\text { furü }{ }^{\prime} \text { al-dìn }\right)^{17}$ di mana penekanannya banyak memenuhi kebutuhan sisi materi manusia, yang penentuannya sesuai dengan situasi dan kondisi waktu dan tempat.

Meskipun tetap ada hubungan erat antara dua sisi tadi, karena dua sisi (materi dan non-materi) manusia juga tidak bisa dipisahkan, namun karena sisi non materi manusia (ruh) tidak berubah ${ }^{18}$ dengan pengaruh waktu dan tempat, maka hal-hal yang berkaitan dengan kebutuhannya pun tidak akan pernah berubah. Sedang karena sisi materi sangat dipengaruhi oleh waktu, tempat, situasi dan kondisi maka wajar saja jika terdapat perubahan pada hal-hal yang berkaitan dengan sisi-sisi materi tersebut. Tentu pernyataan ini bukan berarti membenarkan konsep pluralisme agama/madzhab, sebab jika hal tersebut diartikan sebagai pluralisme yang berarti semua ajaran benar sesuai dengan tuntutan zamannya, maka akan terjadi paradoks. Dikarenakan beberapa hal yang beragam, namun dari sudut yang sama adalah satu, ataupun sebaliknya, adalah hal yang kontradiktif dan tidak dapat diterima oleh akal sehat. Oleh karenanya, dikarenakan ruh dan fitrah manusia adalah satu dan tidak pernah berubah, sehingga disebut berbilang, maka agama yang sebagai pembimbing dan pemimpin esensi manusia pun harus satu pula. ${ }^{19}$ Maka dari itu, perbedaan syari'at antar agama samawi hanya terletak pada sisi zahir saja yang mampu menerima perubahan, disesuaikan dengan tuntutan zaman. Namun dari sisi esensi agama samawi adalah satu, konsep tauhid dengan arti yang sebenarnya. ${ }^{20}$ 
Sebagian para sosiolog agama berpendapat, perbedaan antara agama dan madzhab yang ada bersifat gradual di mana sebagian disifati dengan kesempurnaan, sedang yang lain bersifat lebih sempurna. Perbedaan antara agama dan madzhab yang ada bersifat relatif, bukan paradoks. Pernyataan semacam ini tidak dapat diterima karena relatifitas sesuatu bisa dinilai dari dua hal; adanya sesuatu yang lain untuk dijadikan pembanding (tanpa adanya pembanding relatifitas sesuatu tidak dapat ditentukan), dan perubahan lingkungan yang akan berpengaruh terhadap perubahan objek.

Relativitas dengan dua syarat tadi tidak mungkin barkaitan dengan realitas di luar. Mengingat realitas di luar (realitas luaran) sebagaimana adanya adalah kenyataan yang tidak dapat dipungkiri. Sebagaimana realitas luar tidak dapat dihukumi relatif, pengetahuan manusia pun tidak dapat dinyatakan relative, sebab setiap pengetahuan manusia yang sesuai dengan realitas luar akan dapat dinyatakan benar, sedang jika tidak sesuai maka dinyatakan sala, karena hanya ada satu realitas di luar, maka kebenaran pun tunggal, tidak berbilang. ${ }^{21}$ Benar, gradasi dapat berlaku pada realitas luar, juga pada pemahaman manusia. Jika pemahaman manusia berkaitan pada tingkatan tertentu pada tahapan gradasi tersebut maka dapat dinyatakan benar pada posisinya, namun jika tidak -melesat keluar dari garis lurus dan poros gradasi- maka dapat dipastikan kesalahannya.

Dalam sebuah gradasi kebenaran mensyaratkan empat unsur; keragaman sejati, kesatuan sejati, kembalinya keragaman pada kesatuan sejati dan kembalinya kesatuan kepada keragaman sejati. ${ }^{22}$ Keberagaman agama/madzhab bukan sesuatu yang bersifat relative, baik relatifitas kebenaran maupun pemahaman, namun sesuatu yang bersifat gradasi. Gradasi kebenaran ajaran syari'at terletak pada sudut pandang penyesuaian atas kebutuhan masyarakat setiap zaman, maupun pada sudut pandang persesuaian syari'at dengan tuntutan hakikat kebenaran zaman itu. Hal itu berkaitan dengan cabang agama. Berbeda dari asas dasar, agama sekali lagi tidak tergantung pada hakikat tuntutan zaman dan situasi dan kondisi apapun.

Meskipun pembahasan di atas banyak menyinggung tentang pluralisme agama secara umum, namun inti masalah lebih banyak menjawab pluralisme antar agama samawi. 


\section{Pluralisme Internal Agama}

Munculnya pemikiran pluralisme internal agama sebagaimana pluralisme eksternal agama berangkat dari sebuah keraguan (ragu akan kebenaran). Penerimaan pemikiran pluralisme internal agama ${ }^{23}$ dapat ditinjau dari beberapa asas pemikiran. Pertama, dalam sudut pandang yurisprudensi (usul fiqh), asas pemikiran yang mendasarinya terbagi pada dua hal yang utama musawwibah dan mukhtiah. ${ }^{24}$ Bagi pakar yang meyakini musawwibah, pluralisme madzhab harus bisa ia terima, namun sebaliknya pada yang meyakini mukhṭi'ah. Kedua, jika hakikat kebenaran diyakini sebagai hal yang relatif, maka para pendukung pemikiran ini harus menerima kenyataan adanya pluralisme madzhab. Akan tetapi bagi yang meyakini bahwa kebenaran bersifat mutlak (bukan relatif) dan untuk meraih kebenaran mutlak merupakan suatu yang tidak mustahil, maka pluralisme madzhab tidak bisa diterima. ${ }^{25}$

Ketiga, jika dalam satu madzhab terdapat beberapa pakar yang berbeda dalam memahami teks (istinbāt), perbedaan adalah hal wajar dalam kehidupan. Jika masing-masing pakar dalam usaha memahami teks menggunakan asas dan metode yang dibenarkan, maka dengan hal itu kesalahannya bisa ditolerir. Dikarenakan hal tersebut hanya akan menghasilkan perbedaan-perbedaan dalam hal-hal yang bersifat partikular $\left(\right.$ far $\left.^{(}\right)$), tidak prinsipal. ${ }^{26}$ Karena dalil yang mereka pakai, selama ada kejujuran ilmiah dan spiritual, akan menjadi argumentasi (bujjah) bagi dirinya di hadapan Allah. Jika seseorang yang bukan hanya tidak menggunakan asas dan metode yang benar, namun ia juga dengan sengaja dan lalai dalam mengeluarkan hukum (berfatwa), maka kesalahan yang dilakukannya pun tidak dapat ditolerir dan akan mendapat dosa dan cela.

Dari semua penjelasan di atas, jelaslah bahwa pembenaran atas konsep pluralisme agama ataupun madzhab akan dapat menjerumuskan seseorang pada relativisme, sementara relativisme tidak dibenarkan dengan argumentasi akal yang sehat sesuai dengan kaidah-kaidah logika yang ada. Oleh karenanya sebagian pemikir, untuk menghindari problem-problem yang muncul, mereka menghindari penggunaan istilah pluralisme agama yang berarti pengakuan atas kebenaran semua agama. ${ }^{27}$ Kecuali jika pluralisme agama diartikan sebagai hidup rukun dan damai saling bertoleransi 
secara sosial keagamaan, yang tentunya hal itu berbeda pengertian dari apa yang digagas John Hick. ${ }^{28}$

\section{Penyalahgunaan Konsep Pluralisme Agama}

Kehidupan damai antar pengikut umat beragama bukanlah sekedar basa-basi hubungan sosial-politik. ${ }^{29}$ Kehidupan tentram antar umat beragama tidak dapat didefinisikan bahwa setiap pengikut satu keyakinan selain harus meyakini kesesatan kelompok lain, namun di waktu yang sama mereka terpaksa untuk hidup berdampingan dengan pemeluk keyakinan lain (yang dianggap sesat). Ini karena walaupun setiap pemeluk keyakinan tertentu menyatakan kesesatan pemeluk keyakinan yang lain, namun bukan berarti pemeluk keyakinan yang dianggap sesat dapat dipastikan bahwa mereka adalah penghuni neraka. Tidak ada konsekuensi di antara keduanya. Tidak semua pemeluk kesesatan dapat dipastikan sebagai penghuni neraka, karena boleh jadi kesalahan mereka terletak pada penentuan objek kebenaran. ${ }^{30}$ Atau mereka masih berada di tengah jalan pencarian dan belum sampai kepada kebenaran sejati. ${ }^{31}$ Jika seseorang telah berusaha optimal untuk mencari kebenaran akan tetapi salah dalam penentuan objek riil kebenaran, maka walaupun ia dapat dipastikan tidak mendapat pancaran cahaya kebenaran, namun belum tentu ia masuk kategori penghuni neraka. ${ }^{32}$

Parameter utama dalam mewujudkan kehidupan tentram dan damai antar umat beragama adalah dengan melihat kesamaan antar agama yang ada. ${ }^{33}$ Namun hal ini bukan berarti pluralisme agama dapat dibenarkan. Ini karena agama yang benar adalah agama yang tidak terdapat paradoksi dalam semua ajarannya, terutama dalam masalah keesaan Tuhan. Hanya agama yang benar-benar mengajarkan keesaanTuhan dengan arti yang sesungguhnya saja yang dipastikan kebenarannya dan hal itu tidak akan pernah berbilang.

Perlu diingat, dalam kaitan dengan permasalahan kesempurnaan sejati manusia hanya ada satu jalan yang harus ditempuh agar sampai kepada tujuan yang dikehendaki, bukan berbilang sebagaimana keyakinan pendukung pluralisme agama. Akan tetapi, bagi seorang pejabat pemerintah yang harus mendapat pandangan dan informasi dari berbagai pihak, meskipun pengikut agama lain, untuk 
menyesuaikan kebijakan-kebijakan umum yang akan dikeluarkannya, maka tentu ia tidak boleh memonopoli pikiran seseorang sehingga dengan sesuka hati mengatakan "semua pandangan, kebijakan dan ketentuan saya dijamin kebenarannya”. ${ }^{34}$ Bermusyawarah adalah sesuatu yang baik. Meskipun bermusyawarah berarti mengumpulkan beragam pendapat, akan tetapi bukan berarti menyatakan kebenaran semua jenis pendapat yang beragam. Kebenaran bersifat tunggal, bermusyawarah adalah mengumpulkan keberagaman dari sisi konsep dan bertukar pikiran. Salah satu cara mendapat kebenaran yang tunggal adalah dengan bermusyawarah. Boleh jadi melalui musyawarah kesalahan seseorang akan nampak sedang pihak lain dalam kebenaran, sehingga kebenaran itulah yang dapat dilaksanakan dan diterapkan. ${ }^{35}$

Beberapa pihak yang tidak bertanggungjawab selalu berusaha dengan berbagai cara untuk meneror stabilitas kelompok yang dianggap rivalnya. Berbagai sarana dipakai untuk aksi tersebut, tidak terkecuali dengan konsep pluralisme agama dan madzhab. Dengan mendefinisikan konsep pluralisme agama dan madzhab dengan halhal yang bertentangan dengan rasio sehat manusia dan fitrah suci manusia cukup sebagai bahan untuk meragukan ketulusan tujuan penyebaran konsep tersebut. Adanya usaha penjajahan kebudayaan dan ekspansi hegemoni pemikiran tertentu di dunia adalah salah satu target utama yang ingin mereka capai. Target tersebut tentu tidak akan dapat secara langsung mereka dapatkan kecuali melalui fase-fase sebagai berikut, antara lain: menjauhkan 'kepedulian' penganut agama atas kelangsungan hidup agamanya, menghilangkan 'kesensitifan' penganut agama tertentu atas agamanya dan berusaha 'mengintervensi' norma-norma ajaran suatu agama, untuk memasukkan ide dan pandangan mereka.

Jika diteliti dan dicermati lebih dalam, ketiga fase di atas telah mereka laksanakan dan pada batas-batas tertentu telah menampakkan hasil. Pemikiran modernisme yang dilanjutkan dengan pemikiran post-modernisme adalah salah satu sarana ${ }^{36}$ untuk menggoyahkan keyakinan beragama. Hal itu merupakan jenis kolonialisme dan imperalisme baru. Jelas tujuan utamanya adalah negara-negara dunia ketiga yang sedang berkembang. ${ }^{37}$ Namun patut disayangkan, banyak 
bangsa negara berkembang yang tidak menyadari hal tersebut, sehingga mereka terlebih dahulu silau oleh janji semu para imperalis itu tanpa meneliti dahulu tujuan di balik permasalahan yang ada, atau mereka merasa bangga dengan pemikiran yang diimpor dari bangsa lain yang dianggap lebih maju. ${ }^{38}$

\section{Urgensi Masyarakat Religius}

Jelas sekali, manusia adalah makhluk sosial. Ia tidak bisa hidup tanpa bermasyarakat. Bermasyarakat merupakan salah satu kebutuhan hidupnya. Sedang masyarakat tersusun dari individu-individu yang kemudian berkomunitas. Suatu komunitas akan mendapatkan bentuk kehidupan yang bagus jika setiap individu tidak bermasalah, adanya persesuaian. Persesuaian tidak mesti berartikan kesamaan. Hal itu dikarenakan kesamaan secara mutlak dalam bermasyarakat mustahil terwujud. Setiap pribadi dalam masyarakat mesti memiliki perbedaan, perbedaan dari sisi background pendidikan, status sosial, kemampuan ekonomi dan sebagainya, yang mengakibatkan munculnya perbedaan. Perbedaan alami dan wajar bersifat positif. Akan tetapi individu yang bermasalah akan menjadi kendala bagi masyarakat sekitarnya, perbedaan non-alami yang negatif. Semakin minim keberadaan individu bermasalah dalam sebuah komunitas akan semakin stabil pula komunitas tersebut.

Untuk mengatasi problem keberadaan manusia yang bermasalah, ataupun menahan menyebarnya virus yang bersumber dari sampah masyarakat di tengan-tengah masyarakat sehat, maka perlu dilakukan penyehatan lingkungan. Trik dalam rangka menyehatkan lingkungan memiliki banyak metode yang dapat diterapkan. Menjaga kesehatan lingkungan atau mengobati penderita gangguan kesehatan adalah cara global untuk mewujudkan hal tersebut. Tentu, untuk menjaga kesehatan lingkungan dari gangguan masyarakat yang bermasalah ataupun mengobati virus yang menghinggap pada seseorang harus bekerjasama dengan aparat keamanan setempat, dan bertindak sesuai hukum yang berlaku, tidak bermain hakim sendiri. Dalam proses mengobati individu bermasalah, secara umum, ada dua cara bentuk pengobatan. Mengingat penyakit terkadang disebabkan oleh kurang atau kelebihan suatu zat tertentu dalam tubuh, maka perlu 
ada rehabilitasi guna menstabilkannya sesuai dengan kebutuhan yang ada. Namun jika penyakit itu sudah mencapai tahap akut, terkadang harus diadakan pengorbanan untuk penyembuhannya. Pemotongan (amputasi) asdalah pilihan pahit yang harus dilakukan untuk menjaga kelangsungan hidup. Mengorbankan bagian tubuh masyarakat demi kelangsungan hidup bermasyarakat yang bersih dari penyakit penyebab masalah dalam kondisi tertentu harus dilakukan. ${ }^{39}$

Konsep pluralisme agama hanya dapat menyelesaikan kendala kerukunan antar umat beragama. Namun faktor internal manusia belum tentu akan tuntas dan terselesaikan dengan konsep tadi. Mengingat bahwa dua faktor itu, eksternal dan internal, saling berkaitan erat, maka mengatasi keduanya harus seimbang. Kerukunan akan terealisasi jika pemahaman dan kesadaran beragama telah menyebar ke semua lapisan masyarakat. Tanpa adanya pemahaman dan kesadaran beragama pada masyarakat, arogansi dan premanisme akan terus menjalar bagaikan api dalam sekam yang sewaktu-waktu akan muncul kepermukaan. Yang ada hanyalah kerukunan relatif dan semu (nisbi). Oleh karena itu, konsep pluralisme agama dan madzhab harus bertumpu pada pemahaman dan kesadaran agama yang akan memunculkan identitas agama. Ketika agama dengan berbagai ajaran dan normanya telah menjadi identitas bangsa, maka saling menghargai, menghormati dan toleransi antara sesama -yang ditekankan oleh ajaran setiap agama- akan terealisasi dengan baik. Tidak satu agama pun yang membolehkan, apalagi mengajarkan, mengadakan kerusuhan, merusak rumah ibadah agama lain, penganiayaan, aksi teror yang dapat menyebabkan manusia-manusia tak berdosa turut menanggung dosa.

Manusia memiliki dua dimensi utama; dimensi material dan nonmaterial. Meski kedua dimensi tadi berbeda dari sisi eksistensi, namun keduanya memiliki kaitan yang sangat erat. Sebagaimana dimensi materi manusia dapat bermasalah, dimensi non-materi pun begitu pula. Sebagaimana dimensi materi memiliki berbagai kebutuhan yang harus dipenuhi, dimensi non-materi juga memilikinya. Tentu, kendala dan kebutuhan setiap dimensi disesuaikan dengan eksistensi dimensinya. Dikarenakan dimensi non-material tidak kasad mata (inderawi), sedang umumnya manusia terbiasa dengan hal-hal yang inderawi, 
maka kebanyakan mereka lalai akan kendala dan kebutuhan sisi nonmateri dirinya. Kendala dan kebutuhan non-materi manusia adalah kesehatan dan kesejahteraan spiritual. Kesehatan dan kesejahteraan spiritual hanya bisa didapat melalui jalur agama. Tanpa beragama, manusia akan mengalami masalah kesehatan batin dan kemiskinan spiritual, walau boleh jadi secara zahir (material) tergolong individu yang berada. ${ }^{40}$ Dengan kata lain, karena dalam jiwa (baca: fitrah) setiap manusia terpendam kecenderungan bertuhan dan keinginan beragama (jiwa religi), dan dikarenakan jiwa manusia adalah esensi manusia itu sendiri, maka jika ada usaha untuk menyembunyikan kecenderungan dan jiwa religi tersebut berarti sama halnya usaha untuk menyembunyikan esensi kemanusiaan seseorang.

Negara ideal adalah negara yang dapat menjamin kesehatan dan kesejahteraan bangsanya. Dikarenakan bangsa setiap negara terdiri dari jenis manusia, maka bukan hanya kesehatan dan kesejahteraan material saja yang harus dipenuhi oleh suatu negara, akan tetapi kesehatan dan kesejahteraan spiritual juga harus diusahakan untuk dipenuhi. Jadi negara ideal adalah negara yang berusaha memenuhi kesehatan dan kesejahteraan material dan spritual bangsanya. Hancurnya negara sosialis bukan dikarenakan kehebatan negara kapitalis, karena negara kapitalis pun memiliki kandala yang sangat besar. Bangsa dari negara kapitalis merasakan dahaga spiritual yang sangat parah, yang kebutuhan itu tidak dapat dipenuhi oleh sistem kapitalisme. Hanya kesejukan air religiusitas keagamaan yang dapat menghilangkan dahaga spiritual manusia. Religiustitas keagamaan adalah kebutuhan primer dalam kehidupan manusia.

Namun pada kenyataannya sulit memraktikkan konsep sebuah masyarakat religius. Hal itu selain dikarenakan minimnya tingkat religiusitas bangsa secara umum, juga dikarenakan munculnya banyak aliran pemikiran dalam menyikapi para pengikut agama/madzhab lain. Namun perbedaan yang ada bisa diatasi dengan diadakannya dialog antar umat beragama, sehingga saling pengertian akan keyakinan masing-masing bisa terwujud dengan baik. Dengan dialog toleransi sosial umat beragama akan dapat dicapai, bahkan kebenaran suatu agama akan mudah didapat. Selain itu, tingkat religiusitas bangsa juga harus ditingkatkan, dengan cara membangkitkan identitas 
religius mereka.

\section{Simpulan}

Berdasarkan apa yang telah dibahas dalam makalah ini, pluralisme agama dan madzhab bukan berarti keyakinan akan kebenaran semua agama dan madzhab. Dengan tidak meyakini pluralisme agama dengan arti tadi, sebagaimana yang dicanangkan oleh John Hick, pendiri istilah ini, bukan berarti mengumumkan perang terhadap agama atau golongan lain di luar golongan tertentu, karena tidak adanya konsekuensi di antara keduanya.

Setiap negara berhak untuk menyeleksi aliran dan pemikiran apapun yang akan masuk ke negara yang bersangkutan, tidak terkecuali Indonesia. Oleh karenanya harus ada lembaga tertentu yang memiliki otoritas dan kompetensi untuk menentukan aliran dan pemikiran yang dianggap sesuai. Tentu proses penyeleksian aliran bukan sekedar boleh atau tidak tanpa didasari argumentasi dan bukti yang otentik. Namun proses penyeleksian harus didahuli dengan berbagai tahapan-tahapan logis, termasuk diskusi dengan mendatangkan pihak-pihak yang mewakili dari objek sekte yang akan diseleksi, bukan pengadilan in-absentia. Jika tahapan-tahapan logis itu tidak dilalui atau bahkan begitu saja diabaikan, bisa dipastikan lembaga itu tidak akan memunyai wibawa intelektual dan tidak akan mendapat simpati rakyat. Bagaimanapun juga kepercayaan rakyat adalah kunci penerimaan (maqbülìyah) rakyat akan lembaga tersebut. Hanya agama dan madzhab (sekte) yang diakui oleh pemerintah saja yang dilindungi oleh pemerintah. Tentu pengakuan pemerintah tidak berarti kepastian akan kebenaran agama dan madzhab tersebut. Pengakuan ini berarti agama dan madzhab yang secara resmi diakui oleh pemerintah, berhak untuk mendapat perlindungan. Tentu, dikarenakan setiap ada hak di situ pula terdapat kewajiban, maka agama/madzhab tersebut berkewajiban untuk membangun kehidupan beragama yang baik dan usaha untuk turut serta membangun dan menciptakan stabilitas nasional.

\section{Catatan Akhir:}

${ }^{1}$ Muhammad Hassan Ghadrḍan Gharamleki, Phylosophical Theology, Parsi 
Edition (Wutsuq: 1383 HS), 99-102.

2 Michael L Peterson, Reason and Religius Belief: An Introduction to the Philosophy of Religion (Oxford: Oxford University Press, 1991), 420.

3 Ayatullah M Taqi Misbah Yazdi, Pursyes-ha wa Posyukh-ha Bakhsye Pluralism Dini, Intisyarat-e Muassese-e Omuzesy wa pezuhesy Imam Khumaini ra-Qom.

4 Dua pandangan yang paradoks tidak mungkin bisa diterima kedua-duanya, karena satu pandangan menafikan pandangan lainnya. Dalam ilmu logika Arestotelian disebutkan, sebagaimana bertemunya dua hal paradoks dihukumi mustahil, maka penolakan keduanya pun dihukumi mustahil (istiḥālat ijtimā'alNaqìdayn wa irtifäuhumā). Jadi hanya satu yang memiliki kapasitas kebenaran, bukan berbilang.

5 Ali Rabbani Golpaygani, Makrefat-e Dini az Manzar-e Makrefat Syenosi, Kanun Andisye-e Jawon, I, 1378 HS, 204-206.

6 Yazdi, Pursyes-ha wa Posyukh-ha bakhsye Pluralism-e Dini, Pezuhesy wa Omuzash Imam Khumaini ra Qom

7 Contoh paling jelas adalah yang dilaksanakan oleh Rasulullah di negara Madinnah. Penduduk Madinah kala itu terdiri dari beragam agama, bukan hanya Islam. Di bawah naungan pemerintahan Islam yang dipimpin oleh Rasul masyarakat non Muslim hidup tentram dan damai (pluralisme praktis). Namun apakah hal itu (pelaksanaan pluralisme praktis) berarti Rasul juga mengakui kebenaran Yahudi dan Nasrani (pluralisme teoritis) dan sekaligus beliau meyakini relatifitas kebenaran Islam? Berdasarkan bukti sejarah dan argumentasi rasional serta tekstual agama (Qur'ān dan Hadīts) hal itu tidak dapat dibenarkan. Hal di atas inilah yang sekarang diterapkan oleh Republik Islam Iran berkaitan dengan agama non-Islam dan madzhab non-Syī'ah Imāmīyah.

8 Islam sendiri menyatakan bahwa sangkaan tidak akan menghasilkan apapun sebagaimana yang disinyalir dalam surat Yūnus ayat 36 atau surat al-Najam ayat 28. John Hick, Philosophy of Religion (Parsi Edition), trans. Behzad Salik (Intasyarat al-Huda, III, $1381 \mathrm{HS}$ ), 17.

9 Ayatullah M.Taqi Jakfari, "Falsafe-e Din”, Abdullah Nashri, dalam Pezuhesygoh-e Farhang wa Andisye-e Islami, II, 1378 H S, 506-508.

${ }^{10}$ Segala prinsip logika untuk menjadi kebenaran pasti harus kembali kepada tata cara penerapan silogy (qiyās) dengan bentuk demonstratif (burhān) sedang silogi demonstratif itu sendiri premis-premisnya (mayor-minor) harus dari sesuatu yang necessary (bädihizyah), sehingga hal tersebut bisa dijamin kebenarannya, dimana premis necessary ini bertumpu pada kemustahilan bertemunya dua hal paradox (ijtimā' al-naqdayn) yang masuk kategori necessary preponderances (bädihiyah-awwalìah). Hal itu terkadang bersifat jelas (bayyin) terkadang bersifat penjelas (mubayyin). Untuk penjelasan lebih detail permasalahan, silahkan telaah buku-buku yang berkaitan dengan hal tersebut, dan semua itu telah dibahas secara rinci dalam buku-buku logika, bagi yang berminat menelaah secara terperinci silahkan merujuk buku-buku logika.

11 John Hick, Philosophy of Religion (Parsi Edition), 284-290. Perlu dicatat, ada tiga argumen teologis mendasar yang dipakai untuk menguatkan konsep 
pluralisme agama; pertama pengalaman spiritual (religious experience), kedua simbolisasi bahasa teks agama (pandangan Paul Tillich) dan ketiga pemisahan antara intisari agama dan anggapan kedekatan kepada Tuhan sebagai intisari agama tanpa melihat selainnya. Tanggapan atas argumen di atas perlu tulisan tersendiri tentang: religious experience, sementology agama dan esensi agama.

${ }^{12}$ Misalnya jika air bersifat tidak terbatas maka ia akan memenuhi segala sesuatu sehingga eksistensi lain tidak lagi memiliki kesempatan untuk memiliki wujud nyata.

${ }^{13}$ Al-Qur'ān dalam menyanggah pemikiran ini mengatakan: "Adakah sama orang-orang yang mengetahui dengan orang-orang yang tidak mengetahui? Sesungguhnya orang yang berakal yang dapat menerima pelajaran” (QS. alZumar/39: 9).

${ }^{14}$ Ayatullah Abdullah Jawadi Amuli, dalam Din Syenosyi, Isra', 1381 H S, $207-$ 310.

${ }^{15}$ Oleh karena itu, dalam al-Qur'ān semua ajaran tauhid yang dibawa oleh para nabi disebut dengan Islam (sebagai contoh lihat surat al-Hajj ayat 78) namun apakah Yahudi dan Nasrani sekarang ini masih murni bertauhid? Jawabannya ada pada al-Qur'ān surat Ālu-'Imrān ayat 67

${ }^{16}$ Ungkapan ini mengisyaratkan apa yang telah disampaikan al-Qur'ān dalam surat al-Mäidah ayat 48 tentang pebedaan syari'at Ilahi sesuai dengan kebutuhan dan tuntutan zamannya.

${ }^{17} \mathrm{Hal}$ ini sesuai dengan apa yang dinyatakan oleh al-Qur'ān dalam surat al-Rūm ayat 30: "Tiada perubahan dalam ciptaan Allah".

${ }^{18}$ Oleh karenanya dalam ajaran Islam tidak diperkenankan membeda-bedakan para nabi karena walaupun mereka secara sisi materi karena tuntutan waktu dan tempat berbeda namun ajaran inti mereka adalah satu, tauhid (lih. QS. al-Baqarah/2: 285).

${ }^{19}$ Oleh karenanya, al-Qur'ān sangat menekankan kepada para ahli kitab untuk kembali ke jalan tauhid. Untuk membuktikan penerapan konsep tauhid dengan apa yang para ahli kitab yakini selama ini perlu adanya dialog antar agama, terkhusus antar agama samawi. Manakah dari sekian agama itu yang benarbenar mengajak kepada keyakinan monoteis?

${ }^{20}$ Dalam hal ini al-Qur’ān menyatakan: "Maka tidak ada sesudah kebenaran itu, melainkan kesesatan" (QS. Yūnus/10: 32). Dan sebagaimana banyak ayatayat al-Qur'ān menyebutkan bahwa cahaya (nür) mesti disampaikan dengan kata tunggal, sedang kesesatan (dalālah) ataupun kegelapan (zulumāt)-yang merupakan lawan dari cahaya/kebenaran-mesti disebutkan dengan kata jamak.

21 Lih. kembali karya-karya tentang falsafat transtendental Islam seperti: Bidāyah al-Hikmah dan Nihāyah al-Hikmah karya 'Allāmah Sayyid M. Husein Tabāțabāīi atau Al-Hikmah al-Muta'ālìyah karya Mullā Șadrā berkaitan dengan pembahasan tasykīk al-wujüd (gradasi wujud).

${ }^{22}$ Jika berbicara tentang argument tekstual agama Islam, terlampau banyak ayat maupun riwayat yang mengingkari pluralisme madzhab, salah satu Hadīts 
yang dengan jelas menentang pluralisme ini adalah Hadīts tentang perpecahan Islam menjadi 73 kelompok (dalam riwayat lain 72 golongan) di mana hanya satu kelompok yang ditanggung kebenaran dan keselamatannya. Hadìts ini diriwayatkan dalam kitab-kitab standar Sunnī dan Syī'ah.

${ }^{23}$ Musaāwabah adalah keyakinan bahwa kebenaran tidak memiliki ketentuan yang jelas. Dalam arti, kebenaran sesuai dengan pemahaman seorang mujtahid. Apa yang dipahami oleh seorang mujtahid itulah kebenaran. Sedang mukhtiah adalah keyakinan bahwa kebenaran sudah ditentukan, namun manusia harus berusaha untuk menyingkapnya walau tak jarang ia terjerumus ke dalam kesalahan. Karena kebenaran yang telah ditentukan adalah satu, maka pemahaman tentang kebenaran pun tunggal. Mayoritas mutlak kaum Syīah Imāmīyah pengikut pemikiran mukhțiah.

${ }^{24}$ Problem utama epeistemologi kaitannya dengan masalah ini adalah 1) Adakah sesuatu yang bernama kebenaran absolut? 2) Kebenaran abolut tunggal ataukah berbilang? 3) Mungkinkah manusia dapat menggapai kebenaran absolut? 4) Apakah tolok ukur kebenaran absolut? 5) Sarana apa saja yang dapat menghantarkan manusia kepada kebenaran absolut? Pembahasan secara detail silahkan telaah kembali buku-buku yang berkaitan dengan epistemologi Islam, seperti Al-Manhaj al-Jadìd fì Ta lìm al-Falsafah "bagian epistemology" karya Ayatullah Muhammad Taqi Misbah Yazdi; atau Tafsìr Maudūì (Subject Commentary on The Holy Qurān) Jil: 13 karya Ayatullah Jawadi Amuli tentang epistemologi dalam prespektif al-Qur'ān (epistemology in Qur'ān).

${ }^{25}$ Dalam ajaran Islam, seorang mujtahid jika dengan asas dan metode yang benar telah berusaha optimal untuk memahami teks agama guna menyingkap sebuah hukum syari'at, jika ia ternyata salah dan tidak sesuai dengan kebenaran yang nyata maka diganjar dengan satu pahala, yaitu pahala usaha ilmiah. Jika apa yang diusahakan selama ini benar dan sesuai dengan realita kebenaran, maka ia mendapat dua pahala; pahala usaha ilmiah dan pahala mengamalkan apa yang telah ia dapat (li al-musīb ajrāni wa li al-mukhți' ajrun wähid)

${ }^{26}$ Baca tulisan Alwi Shihab yang berjudul "Menyikapi Pluralisme Agama dan Pluralisme Bersyarat Teladan Nabi" dalam www.republika.com .

${ }^{27}$ Sebagaimana yang disebutkan oleh Richards Glyn dalam karyanya Towards a Theology of Religions yang menyebutkan beberapa pengertian tentang praktik pluralisme agama, di mana sebagian masih bersifat ambigu dan memilki banyak kemungkinan arti.

${ }^{28}$ Islam mengajarkan bahwa orang non-Muslim selama tidak memusuhi dan memerangi maka setiap Muslim harus berbuat baik dan adil kepada mereka (lih. QS. al-Hujurāt/49: 10).

${ }^{29}$ Sebagaimana dalam fiqh Islam manusia jahil (tidak mengetahui) terbagi dua: jahil qașir dan jahil muqasșir, tentu tidak bisa dihukumi sama di antara dua jenis kebodohan tersebut.

${ }^{30}$ Dalam Islam, sesuai dengan ajaran keadilan Ilahi, Allah mustahil menghukum orang yang belum mendapat al-hujjah al-tāmmah, sebagaimana argumentasinya telah ditetapkan dalam teologi Islam. 
${ }^{31}$ Dalam hal ini al-Qur'ān menyatakan: "Dan ada (pula) orang-orang lain yang ditangguhkan sampai ada keputusan Allah; adakalanya Allah akan mengadzab mereka dan adakalanya akan menerima taubat mereka. Dan Allah Maha Mengetahui lagi Mahabijaksana" (QS. al-Tawbah/9: 106).

32 Sebagaimana apa yang diajarkan al-Qur'ān dalam mengajak para ahli kitab untuk menyembah Tuhan Yang Esa tanpa menyekutukan-Nya. (QS. Ālu 'Imrān/3: 64).

33 Al-Qur'ān dalam hal ini menyatakan: "Dan tidak (pula) sebagian kita menjadikan sebagian yang lain sebagai tuhan selain Allah" (QS. Ālu 'Imrān/3: 64). Karena egoisme dan monopoli pandangan adalah bentuk penyekutuan Allah, maka selayaknya bagi seorang pejabat pemerintah untuk mengambil pandangan terbaik walaupun dari pengikut agama/madzhab lain.

${ }^{34} \mathrm{Al}-\mathrm{Qur}$ 'àn dalam beberapa ayatnya sangat menekankan musyawarah, lantas dalam ayat lain menyatakan: "Sampaikanlah berita itu kepada hamba-hamba$\mathrm{Ku}$ yang mendengarkan perkataan lalu mengikuti apa yang paling baik di antaranya" (QS. al-Zumar/39: 17-18).

35 Di samping konsep-konsep epistemologi materialisme, demokrasi (liberal), liberalisme, humanisme dan pemikiran lain yang tidak sesuai dengan ajaran dan semangat agama, terkhusus Islam.

${ }^{36}$ Khususnya negara-negara yang mayoritas penduduknya beragama Islam.

37 Oleh karenanya, berapa banyak kita jumpai para intelektual Muslim terburu silau oleh pemikiran tadi atau kurang peka pada fenomena tersebut, di samping belum siap jika dibilang kurang mengikuti perkembangan zaman dikarenakan mengesamping teori-teori tadi. Akhirnya tak jarang dari mereka memaksakan teks-teks agama untuk menyesuaikan dengan teori-teori di atas, termasuk memaksakan al-Qur'ān dan Hadīts sehingga sesuai dengan konsep pluralisme agama dan madzhab.

${ }^{38}$ Pelaksanaan proses penyembuhan ini dalam Islam dibahas dalam konsep amr ma'rüf nahy munkar. Jika amr ma'rüf dengan dosis ringan tidak berjalan dengan baik maka dalam kondisi-kondisi khusus amr ma'rüf dosis tinggi atau bahkan proses amputasi harus dilakukan yang dalam istilah Islam lebih dikenal dengan konsep Jihad. Logika jihad inilah yang paling ditakuti oleh musuh-musuh Islam. Oleh karenanya, mereka berusaha untuk menghapus konsep ini dari setiap benak umat Muslim dengan cara apapun termasuk dengan memropagandakan bahwa jihad identik dengan fundamentalis, teroris, bertentangan dengan jiwa kemanusiaan dan sebagainya.

39 Sayyid Ali Asghar Kadzimi, Buhran-e Jame-e Modern, Daftar Nasyr Farhang-ge Islami, I, 1377 HS, 103-106.

${ }^{40}$ Oleh karenanya, sebagaimana yang disebutkan dalam lagu kebangsaan kita "Bangunlah jiwanya, bangunlah badannya, untuk Indonesia Raya" mengarah kepada pembangunan jiwa, yang merupakan sisi non-materi manusia, dari sisi spiritual dan religiusitas bangsa, untuk mengimbangi pembangunan material bangsa. 